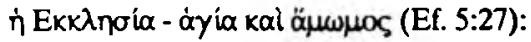

\title{
DIE "HEILIGHEID" VAN DIE KERK TEEN DIE AGTERGROND VAN DIE BREUK KERK-SINAGOGE 1
}

\author{
A.G. van Aarde \\ Departement Nuwe-Testamentiese Wetenskap (Afd. A) \\ Universiteit van Pretoria \\ PRETORIA
}

\begin{abstract}

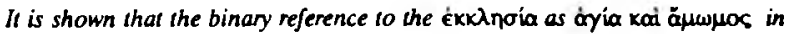
Ephesians 5:27 has to be interpreted in terms of the words $\theta \lambda$ abias kai droke-

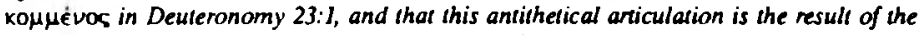

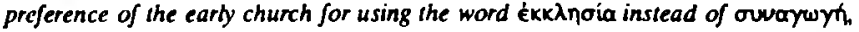
accentuating thereby the inclusive Christian assembly nather than the exclusive cultic community. These conflicting beliefs about the presence of God within the community constitute one of the main features that produced the separotion of Synagogue and Church. The thesis is explored by combining semantic information with the results of recent social-scientific studies of the New Testament. Theoretical and methodological issues, however, ane not entered into.
\end{abstract}

\section{INI EIDING}

Die belydenis dat die kerk een, heilig, algemeen en apostolies is, word nie net so in die Nuwe Testament teruggevind nie. Die byvoeglike naamwoord algemeen, as kwalifisering van die naamwoord kerk, word nie eens in die Nuwe Testament aangetref nie. Sover ons kennis strek, was dit die kerkvader van Antiochië, Ignatius, wat in sy brief aan die gemeente in Smirna(8:2) aan die begin van die tweede eeu n.C., die uitdruk-

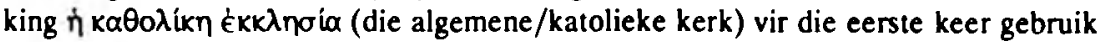
het. Die kwalifisering van die kerk as één, as apostolies, en as heilig word op 'n manier wel in die Nuwe Testament gevind, naamlik in onderskeidelik Efesiërs 4:4; $2: 20$ en

\footnotetext{
1 Verwerking van 'n lesing gehou op 17 Mei 1990 as gasdosent van die Departement Grieks, PU vir $\mathrm{CHO}$. Geldelike bystand gelewer deur die Instituut vir Navorsingsontwikkeling van die Raad vir Gccsteswetenskaplike Navorsing as 'n ad hoc-tockenning aan die outeur vir navorsing oor Die breuk oussen die sinagoge en die kerk word hiermee erken. Menings wat in hierdie artikel uitgespreek en gevolgtrekkings waartoe geraak is, is die van die outcur en moet nie noodwendig aan die INO of die RGN toegeskryf word nie.
} 


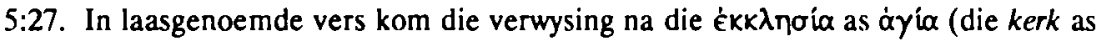
heilig) voor in die sogenoemde "huistafel" waar die huweliksverhouding tussen man en vrou analogies beskryf word na aanleiding van die verhouding tussen Christus en die ÉkKinoia.

In hierdie studie gaan ons nie in op die vroeg-Christelike wortels van die belydenis dat die kerk "een" is (vgl. Ef. 4:4) en "gebou is op die fondament van die apostels en die profete" (vgl. Ef. 2:20) nie (vgl. wel Van Aarde, 1989a). Die interpretasie van Ignatius se siening dat die kerk "katoliek" is, is ook nie nou in die fokus van ons studie nie. Waarin ons geinteresseerd is, is die opmerking in Efesiërs 5:27 dat die kerk "heilig" is. Aan die een kant aanvaar ons dat die verwysing na die "heiligheid" van die kerk nie los verstaan behoort te word van die ander verwysing in Efesiërs 5:27 nie, te wete dat die

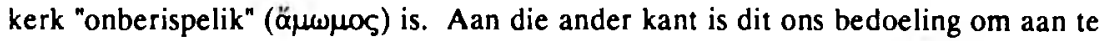
toon dat daar ' $n$ noue verband bestaan tussen die verwysing in die Efesiërbrief dat die ÉKK $\lambda$ noia heilig en onberispelik is en die breuk tussen die sinagoge en die kerk.

Op pad na die verwesenliking van dié genoemde tweeledige doelstelling, poog ons om in hierdie studie 'n saak te beredeneer waarom ons meen dat die woord ékk $\lambda$ noía in die Nuwe Testament doelbewus, naas Jakobus 2:2 as uitsondering, gebruik is om die woord ouvaywy as verwysing na die Christelike geloofsgemeenskap te vervang. Die wyse waarop hierdie aangeleentheid beredeneer word, is deur die semantiek in verband gebring met inligting wat op grond van sosiaal-wetenskaplike ondersoeke verkry is. Teoretiese en metodologiese kwessies word egter vermy.

\section{EKKAH IIA AS TEGNIESE TERM}

Die reformatoriese kerk glo dat die kerk as die gemeenskap van die gelowiges reeds van die begin van die wêreld daar was (vgl. Nederlandse Geloofsbelydenis, art. 27; Heidelbergse Kategismus, Sondagsafd. 21). Die vroegste kerk het hom ook heilshistories op een of ander manier as die voortsetting gesien van die volk van God in die $\mathrm{Ou}$ Testament. In die Nuwe Testament is daar talle aanduidings hiervan en daar bestaan ook baie studies hieroor. Die strekking van titels van boeke soos dié van $\mathrm{H}$. Frankemölle, Jawhebund und Kinche Christi (1974), wat die verband navors tussen die Ou-Testamentiese volk Israel en die kerk waarvan die Matteusevangelie praat, is volop wat baie boeke van die Nuwe Testament betref. Wat die studie van die wooord ékk $\lambda$ noí $\alpha$ in hierdie opsig betref, is daar tradisioneel in byvoorbeeld teologiese woordeboeke (vgl. Schmidt, 1968), maar ook in teologiese werke van Nuwe-Testamentici (vgl. Richardson, 1958:284-286), gepoog om die verband tussen die Ou-Testamentiese ver- 
bondsvolk en die Nuwe-Testamentiese kerk op grond van die vermeende semantiese

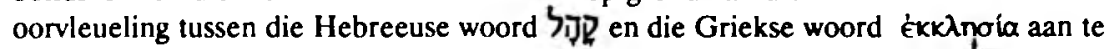

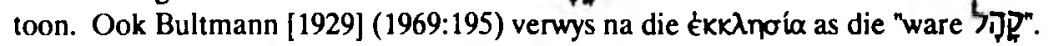

Bultmann, soos vele ander teoloë van sy tyd, is korrek om die Ou-Testamentiese saaklik, hoewel gewysig in belangrike opsigte (vgl. Bultmann, 1969:193-196), gekonti-

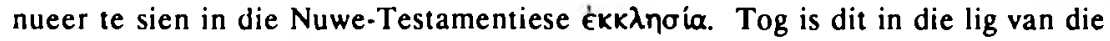
moderne semantiek as onhoudbaar uitgewys om hierdie heilshistoriese kontinuum te beredeneer aan die hand van die semantiese oorvleueling en etimologie van onderskeidelik die woorde relevansie van die saaklike vraag waarom die vroegste kerk veral die woord ékK $\lambda$ noía as selfaanduiding begin gebruik het, oorbodig is nie. Inteendeel, ons is van mening, soos hierbo reeds gesuggereer is, dat die antwoord op hierdie vraag ons kan help om die uniekheid van die Christene, as beweging te midde van die heterogene Joodse gemeenskap in die eerste eeu, beter te begryp.

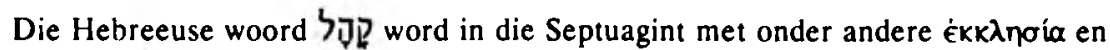
ouvaywyń vertaal. Die Hebreeuse woord עִ word in die Septuagint hoofsaaklik

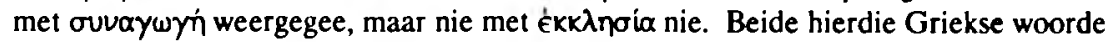
kom egter in sekere kontekste in die Septuagint voor in die betekenis van godsdienstige versameling van mense. In die Nuwe Testament maak dié twee woorde deel uit van die semantiese woordveld sosio-godsdienstige groepering van mense (vgl. Louw \& Nida, 1988:123). Van die ander Griekse woorde wat onder andere ook hierop betrekking

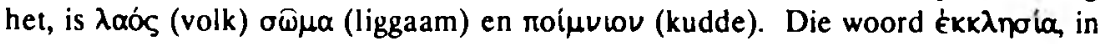
onderskeid met die semantiese komponente van die genoemde en ander soortgelyke woorde, dien as aanduiding van Christene as 'n versamelde groep, behorende tot Christus (vgl. Louw \& Nida, 1988:126), en dit het hoofsaaklik betrekking op die bymekaarkom met die oog op die erediens. Dit kan verwys na 'n spesifieke groep, soos byvoorbeeld in Korinte (1 Kor. 1:2) of na die "ganze Kirche als Einheit", soos byvoorbeeld in Matteus 16:18 (Conzelmann, 1977:394; vgl. ook Louw \& Nida, 1988:

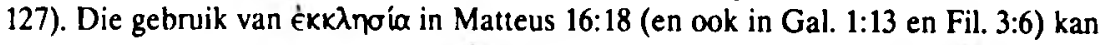
vergelyk word met die gebruik van ékK $\lambda$ noí in onder andere 1 Makkabeërs 2:56 en

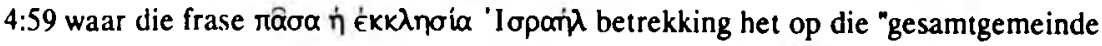
Israels" (Schrage, 1963:191). Wat waarskynlik met die woord ékK noía in sy kollektiewe gebruik uitgedruk word, is dat wat van 'n spesifieke gemeente gesê kan word, ook op ander (konkrete) gemeentes van toepassing was. Rost (1938:155) formuleer dit soos volg: "Der Teil repräsentiert das Ganze, und das Ganze schliesst den Teil ein." Volgens Berger (1976:188) is die komponent "groep/versameling" in die gevalle met 'n 
kollektiewe verwysing beslis nie losgelaat nie, hoewel dit lyk dat dit in hierdie gevalle nie slegs gaan "um eine zum Gottesdienst versammelte Gemeinde" nie.

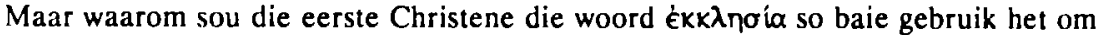
hulle soort groepering aan te dui en nie, behalwe in die geval van Jakobus 2:2 wat die Nuwe Testament betref (vgl. egter die saamgestelde woord émlouvaywyín in Heb. 10:25), die woord ouvaywyn nie? Albei hierdie woorde, het ons gesien, is tog in die Septuagint gebruik om onder andere na die volk Israel as 'n godsdienstige versameling van mense te verwys. Dit is ook op grond van Handelinge 14:43 duidelik dat die woord

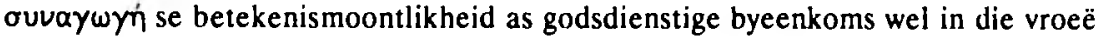
kerk, naas die voorkoms daarvan in die Septuagint, bekend was (vgl. bv. Ignatius, Pol 4:2; Hermas, mand 11:9,13,14; Dionisius van Aleksandrieë, in Eusebius, Hist eccl 7.9:2; 7.11:11,12,17; Justinus, Dial 63:5 - kyk Dibelius [\& Greeven], 1976:133-134).

Christene het klaarblyklik in die vroegste periode van hulle geskiedenis as kerk, toe die breuk tussen die sinagoge en die kerk nog nie 'n voldonge feit was nie, maar ook in die tyd toe die strydbyl al gebêre was, na hulle byeenkoms verwys as ouvaywyn. Ons tese is dat hierdie gebruik aanvanklik uitgesterf het vanweë die sosio-religieuse konnotasie wat daar tydens die breuk tussen die kerk en die sinagoge aan onderskeidelik die

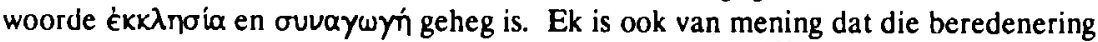

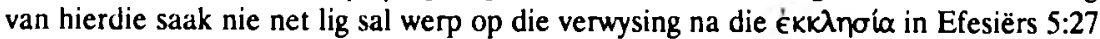
as "heilig" en "onberispelik" nie, maar ook op die uitsonderlike gebruik van die woord

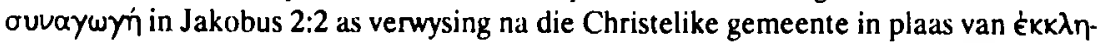
oia. Vereers bespreek ons egter die onhoudbaarheid om die heilshistoriese verband tussen die Ou-Testamentiese verbondsvolk en die Christelike kerk met behulp van etimologie en die vermeende semantiese oorvleueling tussen die woorde

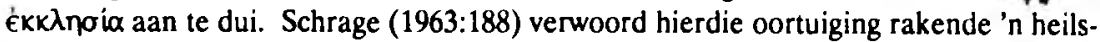
historiese kontinuiteit soos volg:

... die Wahl von ékk $\lambda$ noia ist primär nicht durch das Bewußtsein bestimmt, daß sich die Urkirche in heilsgeschichtlicher Kontinuităt zu Israel damit als legitime Nachfolgerin des altıestamentlichen Bundesvolkes verstand.

Dit was egter veral James Barr (1961:119-129) wat op grond van moderne semantiese insigte die redes aangetoon het waarom die Griekse woord ékx $\lambda$ noía nie sonder meer etimologies teruggevoer moet word na die Griekse werkwoord kaleiv ( $=$ om te roep) en vandaar na die stam ple stem) in die Hebreeus nie. Daar is dus nie grond vir die bewering dat die woord "kerk" op grond van sy sogenaamde etimologiese oorsprong in die uitdrukking "die stem/woord van God", uitgeroepenes sou beteken nie. Die 
uniekheid van die kerk behoort met ander woorde nie gebou te word op die etimologie

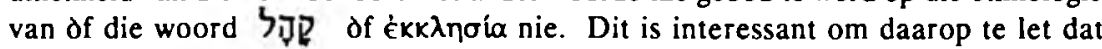
hoewel ook Bultmann (1969:193-195) die kerk se geroepenheid koppel aan die "etimologiese betekenis" van die genoemde Hebreeuse en Griekse woorde, hy nie die uniekheid van die kerk verstaan in terme hiervan nie. Hy self grond die uniekheid van die kerk in die Jesus-gebeure.

Eweneens moet ons die stelling dat die kerk aan die Here behoort (vgl. o.a. Velthuysen 1988:502), nie etimologies grond op 'n siening dat die woord "kerk" afgelei is van die Griekse term k.plakn wat dan sou beteken "om aan die Kúplos te behoort" nie. Afgesien dat die uoord kup akń geen rol in die Nuwe Testament met betrekking tot die kerk speel nie (vgl. Roberts, 1984:286), is hierdie logosentriese en atomistiese tipe semantiek deur die strukturele semantiek agterhaal (vgl. Louw, 1982:23-31). Maar, om dit weer ' $n$ keer te sê, dit beteken nie dat die ondersoek na die betekenis en die gebruik van die woord ékk $\lambda$ noía onbelangrik is nie.

Schmidt (1986:516) het probeer om 'n saak daarvoor uit te maak dat die woord '́kK $\lambda_{\eta}$ oía vir die eerste keer deur die Joods-Hellenistiese Christene gebruik is as aanduiding van die eie aard van die Christelike beweging in onderskeid met die Joodse ouvaywyai. Hy is hierin deur invloedryke Nuwe-Testamentici sterk ondersteun (vgl. o.a. Hahn, 1986:130-131). Hierteenoor het iemand soos Rost (1938:156) gemeen dat dit

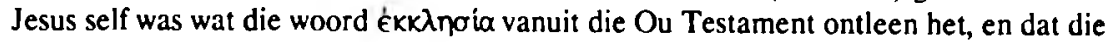
vroeë kerk dit nie eers op grond van latere Hellenistiese invloed op hulleself van toepassing gemaak het nie.

Aan die een kant moet 'n mens egter daarteen waak om ' $n$ te kompartementele skeiding tussen die Jodedom en die Hellenisme op die eerste-eeuse Palestynse bodem te veronderstel, en dit geld ook Egipte en die res van die Diaspora. Aan die ander kant moet 'n mens jou dit kan indink dat die woord ékk noia tog nie in die tyd van die historiese Jesus reeds as terminus technicus gebruik kon gewees het nie. Ons kan ten opsigte van daardie tyd hoogstens van 'n dissipelgemeenskap praat en daar kon nie sprake wees van 'n georganiseerde kerk nie. Daarby moet onthou word dat die byeen-

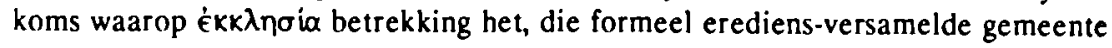
was.

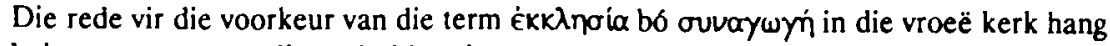
baie nou saam met die sosio-historiese omstandighede van daardie tyd. Dit is 'n tyd wat gekenmerk is deur die Helleniseringsproses. Hierdie proses het reeds voor die geboorte van Jesus 'n aanvang geneem, soos dit gesien kan word in onder andere die 
projek om die Ou Testament in Grieks te vertaal. Hellenisering het konflikte meegebring. Die konflik tussen die Christene en die sinagogale owerhede is juis veroorsaak deurdat die Christene ruimte gebied het vir Helleniste en die feit dat proseliete geakkommodeer is sonder dat daar van hulle verwag is om te naturaliseer. Die bestaan van 'n Aleksandrynse Jodedom by die aanbreek van die Nuwe-Testamentiese periode dui reeds daarop dat dié konflikte reeds vir Jesus op Galilese bodem en vir die eerste Christene ' $n$ aktuele aangeleentheid was. Ons sal later aantoon dat die lering en optrede van Jesus ten diepste hiermee in verband staan.

In hierdie verband is dit daarom van belang om na te gaan hoe die Aleksandrynse Jood, Philo (wat deur Rost die "Septuagint-Jood" genoem word vanweë Philo se ge-

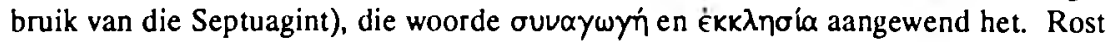
(1938:146-149) het so 'n studie gedoen. Hy het bevind dat ouvaywy' net twee keer by Philo voorkom. Albei kere het dit die betekenis sinagogegebou, dit wil sê die plek van samekoms. Hierdie betekenismoontlikheid kom via die Palestyns-Aramese woord

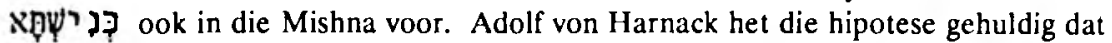
daar juis op grond van dié Aramese woord se betekenismoontlikheid 'n verwarring

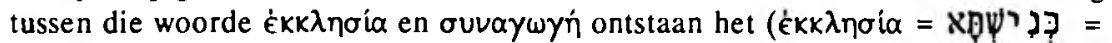
ovvaywyn) met die gevolg dat dit toevallig deur Christene uitruilbaar gebruik is (vgl. Dibelius \& [Greeven] 1976:134 n 59). Daar is ons insiens egter baie meer hierin geleë as blote toevallige verwarring van woorde deur Arameessprekende gebruikers van Grieks. Met die implikasie van eksklusiwiteit wat die betekenis sinagogegebou met hom saamdra, was dit vir alle praktiese redes onmoontlik vir Christene wat uit Jode en nie-Jode bestaan het, om hulleself as groep daarmee aan te dui (Rost, 1983:144-145, 156).

Wat ékk $\lambda$ noía betref, onderskei Rost drie gebruiksareas. Die een is 'n tipe Hellenistiese byeenkoms wat betrekking het op ' $n$ byeenkoms van Griekse gode of burgers van Hellenistiese stadstate. Tweedens het dit betrekking op die sogenoemde Sinaïversameling in die Ou Testament en derdens is daar Philo se allegoriese gebruik daarvan na aanleiding van Deuteronomium 23:1-8. Dit is dus interessant en belangrik om daarop te let dat Philo die woord ékK $\lambda$ noia nie met verwysing na die Joodse gemeente/byeenkoms van sy tyd aangewend het nie. Hoe kan hierdie inligting ons help om agter te kom waarom die woord ékK $\lambda \eta \sigma^{\prime} \alpha$ die tegniese term geword het om die Christene as groep aan te dui?

Ons het reeds daarop gewys dat Rost (1938:145) van mening is dat die Nuwe-Testamentiese gebruik van є̇kk $\lambda \eta \sigma^{\prime} \alpha$ as aanduiding van die Christene as groep sy oorsprong 
het in die Ou Testament en dus nie in die verwysing na die byeenkoms van Griekse gode of die burgers van Hellenistiese stadstate nie. Tog vorm die Hellenisme die agtergrond van dié spesifieke Ou-Testamentiese oorsprong, want dit is die Septuagint wat hier bedoel word en in die besonder Philo se interpretasie daarvan. Dit lyk of die sosio-religieuse agtergrond van die Nuwe-Testamentiese gebruik van EkK $\lambda$ noía as aanduiding van die byeenkoms van Jesus-volgelinge, gesoek moet word in die Aleksandrynse Jodedom se gebruik van die Ou Testament. Hiermee word egter nie beweer dat daar 'n direkte afhanklikheid tussen byvoorbeeld Philo en die skrywers van die Nuwe Testament bestaan het nie. Dit is eerder 'n saak van 'n gemeenskaplike verwysingsraamwerk, te wete die Hellenistiese Jodedom.

Rost (1938:151) is derhalwe waarskynlik reg deur te sè dat Deuteronomium 23:1-8 in hierdie verband 'n baie groot rol gespeel het. Die Hebreeuse uitdrukking קרן Jahwe word in hierdie Ou-Testamentiese gedeelte meer as een keer gebruik. In die Ou

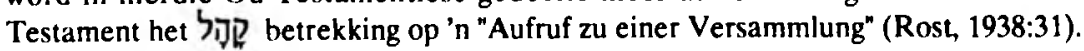

Aufgebot umfaßt mil Ausnahme von Jer. 44,15 und Esr. 10,1: Neh. 8,2-17 nur den ... die
Gesamtheit der mannlichen Volbürger. Die ausgenommen Sicllen ziehen auch Frauen (und
Kinder) zum Aufgebot heran DY Zweck des Aufgebots ist der Zusammentritt der Mannschaft
zur kultischen Feier, zur Gerichtszitzung oder zum Heerzug (Rust, 1938:31-32).

Kritzinger (1957:11) stem met Rost saam dat daar vele tekste in die Ou Testament is wat daarop dui dat slegs volwasse mans of 'n deel van hulle as lede van die "volksvergadering" gereken is. Maar hy meen ook dat daar ander tekste is "waar nie met sekerheid vasgestel kan word of DY slegs manne of ook wel vrouens en kinders aandui nie" (Kritzinger, 1957:11). Hoe dit ook al sy, in Deuteronomium 23:1-8 word die bepalinge gevind oor wie lid mag word van die Onder andere was die volgende persone vir altyd uitgesluit: iemand wie se geslagsor-

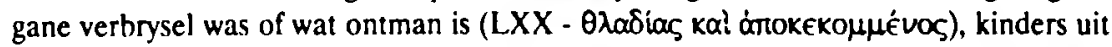
"gemengde huwelike", Ammoniete en Moabiete. Kinders uit die derde geslag Edomiete en Egiptenaars mag egter lid geword het. Die herhaaldelike gebruik van hierdie perikoop is in die Septuagint elke keer met ÉkK $\lambda$ noía weergegee.

Terwyl die woord ouvaywyí naas die tegniese betekenis van sinagogegebou wat dit (onder andere?) by Philo begin kry het, elders steeds op die partikulier-Joodse eksklusiewe gemeente gedui het en normaalweg as die ol 'Ioufaîo bekend gestaan het (vgl. Rost, 1938:156; vgl. ook die Matteus- en Johannesevangelie), het die woord ÉkK入noía se gebruik in hierdie verband egter 'n ontwikkeling ondergaan. Hierdie verandering 
ten opsigte van verwysing het klaarblyklik onder die invloed van die universeelgeorienteerde Hellenisme plaasgevind. Waar die Ou-Testamentiese Godsbegrip hoofsaaklik ingevul is vanuit 'n partikulier-nasionale perspektief, daar was die invloed van die Hellenisme op die Jodedom met die aanbreek van die Nuwe-Testamentiese periode reeds so sterk dat die partikularisme in die Aleksandrynse Jodedom oorgegaan het in 'n soort universalisme (vgl. Aalders, 1985:17-18). Dit is veral in die werk van Philo sigbaar (vgl. o.a. Baur, [1853] 1860:19-20). Kenmerkend van hierdie fase was die ywerige proselietmakery deur die Jode. Philo het die doel daarvan nie gekoppel aan 'n magstrewe wat moes uitloop op die vernietiging van Israel se vyande nie. Volgens hom wou die Jode 'n "geestelike sending" vervul. Imperialisme was nie die bedoeling van die sending nie. Philo het die verhouding waarin die Jodedom tot die ganse mensdom staan, voorgestel as die verhouding tussen die priester en die staat (vgl. Aalders, 1985:29-30) - dit wil sê daar is raakpunte tussen hom en byvoorbeeld Paulus (en Luther) wat die kerk en die staat as aparte soewereine instellings gesien het hoewel die evangelie politieke konsekwensies het, maar "het hemelse moet het niet zoeken bij het aardse" (Vos, 1986:39-40).

Philo se houding kan onder andere gesien word in sy allegoriese uitleg van Deuteronomium 23:1-8. Dit is egter ook iets wat in Deutero-Jesaja (vgl. Jes. 56:37) en die Kronistiese geskrifte, naamlik Esra en Nehemia gesien kan word. Laasgenoemde geskrifte het in die oproep tot die kultiese byeenkoms (aangedui in die Septuagint met die

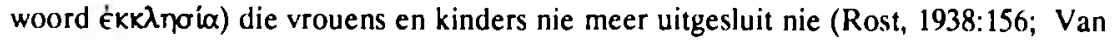
Aarde, 1989b:17-18). Philo self het provokerend die gelykheid van mense wat betref hulle aanneming deur God - afgesien van hulle sosiale posisie en rol - bepleit (vg!. Theissen, 1987:199 $\mathrm{n}$ 3). In sy allegoriese uitleg van Deuteronomium 23:1-8 het hy die eksklusiwisme ten opsigte van Ammoniete en Moabiete toegepas op politeïste en ateiste, terwyl hy die verwysing in Deuteronomium 23:8 na dic toelating van die derde geslag Egiptenare en Edomiete aktualiserend toegepas het op die opneem van die pro-

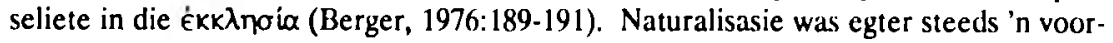
waarde.

Die deurbreking van die partikularisme het in die Nuwe Testament op verskillende maniere neerslag gevind. Die verskil in hierdie verband tussen die Aleksandrynse Jodedom en die Joodse Christendom, geinisieer deur Jesus in aansluiting by bepaalde Ou-Testamentiese tradisies (vgl. bv. Jes. 56:37; 66:1; Esra 10:1; Neh. 8:2-17; vgl. ook Jer. 44:15), is dat naturalisasie nie meer voorwaarde was nie. Waar die eksklusiwisme van Deuteronomium 23:1-8 op die Jerusalemse tempel toegepas is, deurdat dit die uitleg van die tempel se aparte voorhowe bepaal het, daar is dit opvallend dat Jesus byvoorbeeld in die Lukasevangelie geteken word as iemand vir wie die tempel sonder 
verskillende voorhowe was. Conzelmann (1963:123) formuleer Lukas se visie op die tempel soos volg:

Lk hat alierdings cin vercinfachtes Bild des Tempels und scine Areals (s zu $3^{1} \mathrm{ff}$ ): er unterscheidet nicht zwisschen den verschiedenen Vorhöfen, sondern sieht das iepdv als einheitlichen Bezirk, zu dem nur dic Juden Zugang baben.

In die Matteusevangelie (soos ook in Markus, Lukas en Johannes) word vertel dat Jesus die tempel verruim het. Matteus, byvoorbeeld, vertel nie net van die skeur van die voorhangsel van die tempel (Matt. 27:51) en die geloofsbelydenis van 'n nie-Jood (Matt. 27:54) na aanleiding daarvan nie. Matteus vertel ook dat Jesus blindes en kreupeles, as "onrein" sosio-religieuse randpersone, év $\tau \widehat{\varphi}$ lep⿳亠 (= in die tempel) gesond gemaak het (Matt. 21:14) en dat kinders év $\tau \widehat{\varphi}$ lep⿳亠 (= in die tempel) Hom as die Seun van Dawid geloof het (Matt. 21:15). Die vertellinge in Handelinge oor die genesing van verlamdes en kreupeles in 'n Samaritaanse stad (Hand. 8:7) en die gelowig word en doop van mans én vrouens (Hand. 8:26-39; vergelyk ook die verwysing na Klemens van Aleksandrië in Berger, 1976:196, n 190), kan ongetwyfeld ook in verband gebring word met die deurbreking van eksklusiwisme en ostrasisme.

Net so steek daar baie meer in die allegorese van Efesiërs 5:27 waar daar oor die

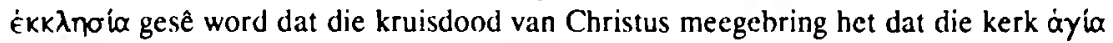
kai ă $\mu \omega \mu$ os (= heilig en onberispelik) is. Volgens Origines is dit woorde wat antiteties

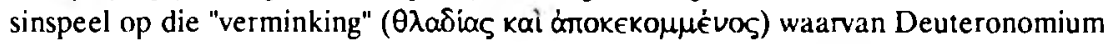
23:2 praat en wat juis die rede was waarom so ' $n$ persoon geostraseer is en nie lid van die ékk $\lambda$ noía kon wees nie. Origines (vgl. Berger, 1976: $190 \mathrm{n}$ 120) het op grond

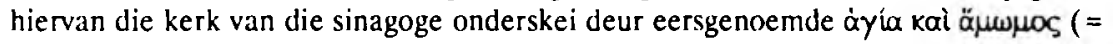
heilig en onberispelik) te noem. En dit lyk of Origenes se interpretasie van Efesiërs $5: 27$ korrek is.

\section{AITA KAI AMOMOE IN EFTSSIēRS 5:27}

In Efesiërs 1:4 sê die skrywer dat dit heel aan die begin God se bedoeling met die mens was dat die mens "heilig en onberispelik" voor Hom sal lewe. Om "heilig" te wees omdat God "heilig" is, is inderdaad die kernwaarde wat in die Judaisme geld (vgl. Van

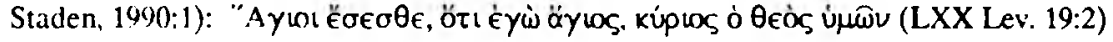
= "Wees heilig, omdat Ek, die Here julle God, heilig is". Hierdie dictum is vir die Jood dié kernwarheid, omdat dit ' $n$ analogiese formule is waardeur die mens in relasie met

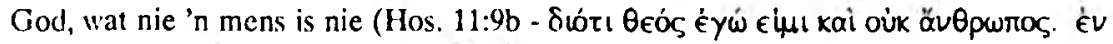
бoì ăy 
In hulle alledaagse lewe het die Jode hierdie verhouding tot God uitgedruk gesien in die belydende Shema-gebed. Hierdie gebed bevat die belydenis dat die God van Isracl die enigste God is. Dit bevat ook die implikasie dat God Israel onderskei van alle ander nasies (vgl. Neyrey, 1988:82). Die implikasie daarvan is dat God se "heiligheid" gerepliseer word in die alledaagse lewe. Alle dinge in die skepping behoort dus hiervolgens uitdrukking te wees van die goddelike orde met betrekking tot sowel klassifikasie as diskriminasie (Neyrey, 1988:68). Hierdie "goddelike orde" word

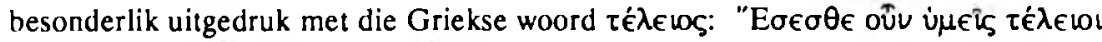

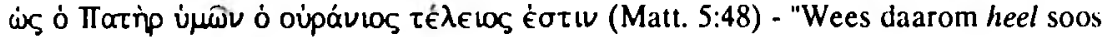
julle hemelse Vader heel is". Douglas (1966:54) stel dit soos volg: "... to be holy is to be whole, to be one; holiness is integrity, perfection of the individual and of the kind" (vgl. ook Van Staden, 1990:3). Hierdie "heelheid" het ook gegeld ten opsigte van byvoorbeeld die offerdier asook die offeraar.

Om dus "heilig" te wees soos God "heilig" is, is om by God te pas, dit wil sê om

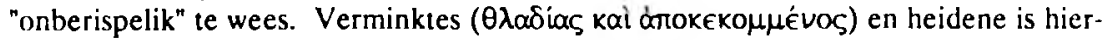
volgens nie aanvaarbaar vir God nie, en is derhalwe ook nie toegelaat om in die kultiese ruimte waar God woon, die tempel (Neyrey, 1988:67), of die vergadering van die "heiliges", die לT? neer dat die Jode God se teenwoordigheid gereguleer het. Hulle Godsbegrip kom daarop neer dat God as beperk teenwoordig by die mense voorgestel is. Die regulasies waarmee God as afwesig of teenwoordig verklaar is, het uit die talle reinheidsvoorskrifte bestaan. Dit het veral die tempel, die tempeltoebehore, die tempelpersoneel en die aanbidders in die tempel gegeld (vgl. Neuser, 1973). In die tyd van Jesus was dit in hierdie verband 'n ernstige dispuutpunt tussen die Sadduseërs en die Fariseërs of die tempelmaatreëls ook in die alledaagse lewe behoort te geld (vgl. Saldarini, 1988:234). Die Fariseërs se teologie het veral gewentel om die strewe dat die tempel en wat daarmee saamgaan, in die alledaagse lewe gerepliseer moet word. Hiervoor het hulle nie net die "Ou Testament" ingespan nie, maar ook "die tradisies van die oudstes" (vgl. Mark. 7:3). Hulle het 'n omvattende klassifikasiesisteem opgestel waarvolgens feitlik alles in die alledaagse lewe in terme van aanvaarbaarheid, of "heiligheid", gerangskik is. Neyrey (1988:76) verwys in aansluiting by Mary Douglas (1966), hierna as "boundaries" en praat van maps of time, maps of persons, maps of things en "perhaps it is fair to say that their primary map was a map of meals". Maaltye is 'n belangrike sosiologiese meganisme wat kontrole uitoefen ten opsigte van reinheid al dan nie. Dit het ook direk betrekking gehad op die handhawing van "boundaries" met betrekking tot vermyding van 'n ondertrouery tussen Jood en nie-Jood sodat die integriteit van die familiale gemeenskap beskerm kon word. 
Die Farisese replisering van die tempelgemeenskap na die alledaagse lewe het die religieuse implikasies gehad dat sosiale ostrasering gelegimiteer is met Godsvervreemding. Dit is in hierdie verband dat Matteus na die inwoners van Galilea, die land van die "heidene" (Matt. 4:15), verwys as diegene wat woon in die land van die skaduwee van die dood (Matt. 4:16). Vir dié sosio-religieuse geostraseerdes, die "volk wat in duisternis lewe", was die evangelie van Jesus, naamlik dat die koninkryk van die hemel naby gekom het, as 't ware 'n lig wat opgegaan het (Matt. 4:16).

Net soos die Fariseërs het Jesus ook gemeen dat dic tempelgemeenskap na die alledaagse lewe gerepliseer moet word. Anders as sy Farisese opponente het Hy by die Ou-Testamentiese verruiming van die tempel aangesluit. Jesus het die sosio-religieuse ostrasering teëgestaan. Hy self, as sosidal-veragte (vgl. Van Aarde, 1988:843), het nie Godsvervreemding ervaar nie, maar wel Godsteenwoordigheid. Sy boodskap dat God se koninkryk in en deur sy lewe 'n werklikheid geword het. getuig hiervan. Dit kan ook gesien word in byvoorbeeld die eksorsisme van die heidense vrou se kind (Mark. 7:2430), die genesing van die doofstomme (Mark.7:31-37) en die blinde aan uie se oë Jesus onrein spoeg sineer (Mark,8:22-26). Hy ven'ang met ander woorde nie die tempel soos die Esseners beoog het nie (vgl. Van Aarde, 1990:12); net soos die Fariseers repliseer Hy die tempelmaatreëls, maar anders as die Fariseërs vemuim Hy die tempel met die gevolg dat die sosiaal-veragte by maaltye by huise (Mark. 12:39) sowel as in die tempel (Mark. 12:41.44) welkom is. Dit is waarop sy reiniging van die tempel neergekom het toe Hy volgens Markus 11:17 aanhaal uit Jesaja 56:7: hicrvolgens is die tempel 'n huis van gebed vir alle mense.

Die Efesiërbrief kontinueer dié Jesus-saak. In E:fesiêrs 2:11-22 sê die skrywer pertinent vir wie hy sy bricf bedoel het (vgl. Roberts, 1983:62-63). Hulle was mense wat tot onlangs toe heidene was ("onbesnedenes"), "uitgesluit van die burgerskap van Israel" (vgl. ook Deut. 7:6-9), "vreemdelinge", "sonder God", "ver van God". Maar die "muur wat skeiding maak", verwysend na die voorhangsel in die Jerusalemse tempel, is afgebreek. Christus het die tempel verruim met die gevolg dat 'n "geestelike huis" gebou is waarin "God woon" - 'n "heilige tempel" ( vaós áyloc ḱv kupíw). Nou hoef die

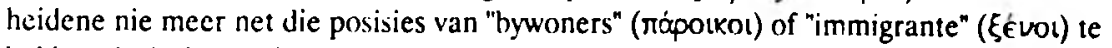
beklee nie (vgl. ook Elliott, 1981). Op grond van die versoeningswerk van Christus het hullc deel geword van die gemeenskap van die "heiliges", leje van die "huisgesin van God". Hierdie gebeure geskied telkens opnuut in die Woord-gebeure. In Efesiërs $5: 26$, as deel van die "huistafel" en met betrekking op wararkynlik die huwelik tussen

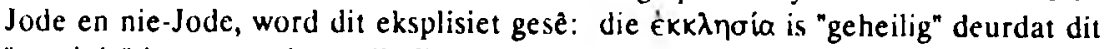
"gercinig" is op grond van die Woord-en die doopgebeure. Die gevolg is dat die ckK入noía "heilig" en "onberispelik" is (Ef. 5:27). 


\section{SAMEVATTING}

Ons het gesien dat die vroeë kerk in aansluiting by die Septuagint onder andere die

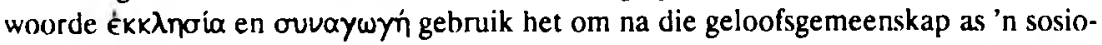
religieuse groepering te verwys. In die kringe van die Hellenistiese Jodedom het laasgenoemde woord die nasionaal-partikuliere konnotasie bly behou wat vroeër ook ten opsigte van die ÉkK $\lambda$ noi $\alpha$ bestaan het. Hiervan is die vermeldinge oor die eksklu-

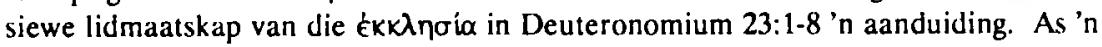
eksponent van die Hellenistiese Jodedom het Philo Deuteronomium begin herinterpreteer. Teenoor die Joods-partikularistiese deelname aan die ouvaywyń as godsdienstige versameling of as toelating tot die ouva $\gamma \omega \gamma \eta$ as kultiese ruimte, is die woord $\dot{E} k k \lambda \eta{ }^{\prime} \alpha$ begin gebruik as aanduiding van die geloofsgemeenskap wat onder andere ook proseliete kon insluit. Daarom was dit 'n term wat veral bruikbaar geword het om na die Jesus-beweging te verwys. Die onderskeidende gebruik van die woorde ékK $\lambda \eta$ oia en ouvaywyń in die vroeë kerk kan met ander woorde verstaan word teen die agtergrond van die breuk tussen kerk en sinagoge. Hierdie konflik het veral verband gehou met die feit dat die Jesus-beweging mense begin akkommodeer het wat vroeër in die Joodse samelewing geostraseer is. In hierdie verband is die Efesiërbrief bekend vir sy pleidooi dat onder andere heiden-Christene onverhinderd as deel van die volk van God gesien behoort te word. Die breuk kerk-sinagoge vorm derhalwe die konteks van die besondere nuanserings wat die woord ĖkK $\lambda$ noi $\alpha$ in die Efesiërbrief gekry het.

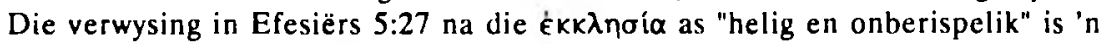
voorbeeld hiervan.

\section{BIBLJOGRAFIE}

AALDERS, G.J.D. 1985. Synagoge, kerk en staat in de eerste vijf ceuwen. Kampen : Kok.

BARR, J. 1961. The semantics of Biblical language. Oxford : Oxford University Press.

BAUR, F.C. [1853] 1860. Das Christentum und dic christliche Kirche der drei ersten Jahrhunderte. 2. Auf. Tübingen : $L$ Fr Fues.

BERGER, K. 1976. Volksversammlung und Gemeinde Gottes: Zu den Anfängen der christliche Verwendung von ékK $\lambda$ noia. ZThK, 73:167-207.

BULTMANN, R. [1929] 1969. Church and teaching in the New Testament. (In Funk, R.W. cd. Faith and understanding, I. Transl. by L.P. Smith. London : SCM. p. 184-219.) (The Library of Philosophy and Theology.)

CONZELMANN, H. 1963. Die Apostelgeschichte. Tübingen : Mohr. (HNT.)

CONZELMANN, H. 1977. Geschichte des Urchristentums. (In Conzelmann, H. \& Lindemann, A., Arbeitsbuch zum Ncuen Testament. 3. Auf. Tübingen : Mohr. p. 282-432.)

DIBELIUS, M. [\& GREEVEN, H.] 1976. James: A commentary on the Epistle of James. Edited by $H$. Greeven and translated by H. Kocster. Philadelphia : Fortress. (Hermeneia.) 
DOUGLAS, M.T. 1966. Purity and danger. London : Routledge \& Kegan Paul.

ELLIOTT, J.H. 1981. A home for the homeless. Philadelphia : Fortress.

FRANKEMoLLE, H. 1974. Jahwchund und Kirche Christi: Studien zur Form- und Traditionsgeschichtc des "Evangeliums" nach Matthäus. Münster : Aschendorf.

HAHN, F. 1986. Die Einheit der Kirche und Kirchengemeinschaft in Sicht. (In Hahn, F. Exegetiese Beiträge zum okumenische Gespräch: Gesammelte Aufsătze, Band I. Göttingen : Vandenhoeck. p. 116-158.)

KRITZINGER, J.D. 1957. Qehal Jahwe: Wat dit is en wie daaraan mag behoort. Kampen : Kok.

LOUW, J.P. 1982. Scmantics of New testament Greek. Philadelphia : Fortress.

LOUW, J.P. \& NIDA, E.A. 1988. Greek-English lexicon of the New Testament based on semantic domains, Volume I: Introduction and domains. New York : UBS.

NEYREY, J.H. 1988. A symbolic approach to Mark 7. Forum, (4)3:63-91.

NEUSNER, J. 1973. The idea of purity in Ancient Judaism. JAAR, 43:15-26.

RICHARDSON, A. 1958. An introduction to the theology of the New Testament. New York : Harper \& Row.

ROBERTS, J.H. 1983. Die Bricf aan die Efesiërs. Kaapstad : NG Kerk-Uitgewers.

ROBERTS, J.H. 1984. Die kerk by Paulus. (In Du Toit, A.B. red., Handleiding by die Nuwe Testament. Band V: Die Pauliniese briewe: Inleiding en teologie. Pretoria : NG Kerkbockhandel. p. 282319.)

ROST, L. 1938. Die Vorstufen von Kirche und Synagoge im Alten Testament: Eine wortgeschichtliche Untersuchung. Stuttgart : Kohlhammer. (BWANT 76.)

SALDARINI, A.J. 1988. Pharisees, Scribes, and Säducees in Palistinian society: A sociological approach. Wilmingion : Glazicr.

SCHMIDT, K.L. 1968. s v ExKAnoia TDNT, Vol. III. Third printing. Grand Rapids: Eerdmans.

SCHRAGE, W. 1963. 'Ekx nojia und Euvaywyt: Zum Ursprung des urchristlichen Kirchenbegriffs. ZThK, 60:178-202.

THEISSEN, G. 1987. The shadow of the Galilean: The quest of the historical Jesus in narrative form Transl. by J. Bowden. London : SCM.

VAN AARDE, A.(i. 1987. Gedagtes oor die begin van die kerk - 'n geskiedenis van versoenende verskeidenheid. HTS, 43:325-373.

VAN AARDE, A.G. 1988. Jesus en die sosiaal-veragtes. HTS, 44:829-846.

VAN AARDE, A.(;. 1989 b. 'n Nuwe Testamentiese begronding van die eenheid van die kerk en die eis om kcrkcenheid vandag. HTS, 45:461-475.

VAN AARDE, A.G. 1989b. Hand 7:48 - "Dic Allerhoogste woon nie in mensgemaakte konstruksies nic ...": Die relevansie van die Nuwe-Testamentiese wetenskap na aanleiding van die metafoor tempel. Pretoria : Van Schaik. (UP Nuwe Recks Nr. 259.)

VAN AARDE, A.(i. 199x). "The Most High God does live in bouses, but not houses built by men ...: The relativity of the metaphor Temple in Luke-Ads. New Testament Report delivered at the International Mecling of the Socicty of Biblical Litcrature, 5-8 August 1990 Vienna.

VAN STADEN, P. 1990. Compassion - the essence of life: A social-scientific study of the religious symbolical universe in the ideology/theology of Luke. Pretoria. (D.D. Dissertation - UP).

VELTHUYSEN, G.C. 1988. Die wese van die kerk: 'n Teologiese antwoord op 'n filosoliesc vraag HTS, 44:489-513.

VOS, J.S. 1986. "Mijn koninkrijk is niet van deze wereld": Geloof en politiek in de vroegchristelijke theologie. (In Veenhof, J., Vos, J.S. \& Werkman, LA. ned. Het rijk Gods en de aardse macht: Theolıgische visies op de verhouding van geloof en politiek. Kampen : Kok. p. 33-45.) 
